\title{
Die einde van die wêreld: Die uitdaging van die moderne natuurwetenskappe aan die tradisionele eskatologie
}

\begin{abstract}
Author:
Klaus Nürnberger ${ }^{1}$

Affiliation:

${ }^{1}$ Department of Dogmatics and Christian Ethics,

University of Pretoria,

South Africa

Note:

Prof. Dr Klaus Nürnberger participates as research fellow in the Department of Dogmatics and Christian Ethics of the Faculty of Theology at the University of Pretoria. Prof. Nürnberger was awarded a Honorary Doctorate in Theology from the University of Pretoria, South Africa on 10 April 2012 The degree is bestowed in recognition of Prof. Nürnberger's outstanding contribution to Biblical Reformed Theology in South Africa and internationally. Prof. Nürnberger is professor emeritus of the University of KwaZulu-Natal.
\end{abstract}

This article was re-published with the corrected affilation of the author.

Correspondence to: Klaus Nürnberger

Email:

info@klaus-nurnberger.com

Postal address:

21 Farmers Folly,

Lynnwood 0081

South Africa

Dates:

Received: 30 Mar. 2012

Accepted: 06 June 2012

Published: 17 Oct. 2012

Re-published: 18 Oct. 2012

How to cite this article: Nürnberger, K., 2012, 'Die einde van die wêreld: Die uitdaging van die moderne natuurwetenskappe aan die tradisionele eskatologie', HTS Teologiese Studies/ Theological Studies 68(1), Art. \#1254, 10 pages. http://dx.doi.org/10.4102/ hts.v68i1.1254

(C) 2012. The Authors. Licensee: AOSIS OpenJournals. This work is licensed under the Creative Commons Attribution License.
The end of the world: The challenge of modern science to traditional eschatology. In biblical times the 'Word of God' indicated God's creative and redemptive response to changing human predicaments and depravations. Redemptive events became traditions that were applied to new situations. Many biblical future expectations lost their relevance and plausibility already within canonical history. Modern science has rendered a literal interpretation of the most recent and radical biblical future expectations - resurrection and a 'new heaven and earth' - problematic. Apocalyptic deliberately employed enigmatic symbols and metaphors to indicate God's miraculous intervention to change an evil world into a new and authentic reality. This motif can be reconceptualised as God's vision for the comprehensive optimal well-being of humanity within the well-being of creation as a whole, which translates into God's concern for any deficiency in well-being in any dimension of life. The emergence of the notion of resurrection to face judgement was rooted in concern about God's justice (theodicy) rather than the longing for never-ending life. The resurrection of Jesus was deemed God's affirmation of his messianic authority to proclaim and enact God's redeeming love, thus its validity for all times and places - which opened up participation in the new life of Christ in fellowship with God for all people.

\section{Inleiding}

Teologie is die poging van gelowiges om te verstaan wat hulle glo (Anselmus se fides quarens intellectum). Soos alle wetenskaplikes kies teoloë 'n uitgangspunt en kyk hoe ver hulle daarmee kom. As dit nie slaag nie, moet hulle weer dink. Die uitgangspunt wat ek gekies het, begin en eindig by die ervaring van die mens. Enige soort spekulasie word vermy. Daar word gevra op watter konkrete noodsituasies die verkondiging van die Bybelse skrywers geantwoord het; daar word gevra watter taalkundige middels hulle daarvoor gebruik het; daar word onderskei tussen beeldspraak en letterlike betekenis; daar word onderskei tussen die ervaring van die werklikheid, wat algemeen toeganklik is, en die verkondiging van God se welwillendheid wat in die geloof aanvaar word (of nie aanvaar word nie).

Daar is twee redes hoekom ek hierdie benadering vandag as noodsaaklik beskou: eerstens, die moderne beskawing het wêreldwyd oorheersend geword. Mense wat die wetenskaplike wêreldbeskouing aangeneem het, sal nie maklik 'n wêreldbeeld of 'n verklaring van die werklikheid aanvaar wat op verouderde aannames gegrond is nie. Die aarde wentel om die son en nie die son om die aarde nie. Ons moet 'n moderne mens vir die moderne mens word, om die moderne mens te kan oortuig (1 Kor 9:19-23). Ek probeer dus nie om 'n 'brug' te bou tussen die moderne wêreldbeeld en die verskeie antieke wêreldbeelde wat ons in die Bybel kry nie, maar om die eintlike boodskap in die antieke wêreldbeeld-verpakkings te ontdek en in terme van die moderne wêreldbeeld te verwoord.

Tweedens, dit is slegs hierdie benadering wat die gaping tussen my eie geloof en my beter wete kan oobrug. Ek het self ' $n$ natuurwetenskaplike agtergrond. Ek kan self nie aanvaar dat die son eers na die plante geskep is nie (Gen 1:12-19), of dat die vrou eers geskep is nadat die man onder die diere nie 'n maat kon vind nie (Gen 2:18-25). Die moderne Bybelwetenskap weet ook dat dit nooit letterlik so bedoel was nie. Ek kan ook nie meer aanvaar dat ' $n$ vader die reg het om sy eie dogter as slavin te verkoop nie (Eks 21), of dat ' $n$ volk die goddelike opdrag het om ' $n$ land binne te val en sy bewoners uit te roei nie (1 Sam 15).

Dit is ook nie nodig om al hierdie dinge te glo as jy 'n Christen wil wees nie. Ons moet erken dat die goddelike waarheid nie in ' $n$ volmaakte vorm uit die hemel geval het nie. Die Bybel is oor ' $n$ tydperk langer as 'n duisend jaar geskryf (omtrent $1000 \mathrm{vC}$ tot $100 \mathrm{nC}$ ). Gelowiges was met baie antieke kulture in kontak. God se Woord het die menslike geskiedenis binne getree, die mense opgetel waar hulle was, en hulle 'n entjie vorentoe laat beweeg. Die insig van gelowiges het in 
Bybelse tye stap vir stap ontplooi en dit ontvou nog steeds. Ek het die navorsing agter hierdie stelling breedvoerig uiteengesit in Nürnberger (2002:39-64). As ons geloof nie bybly nie, word dit oneerlik en irrelevant.

Ook die geloofwaardigheid van ons boodskap is op die spel. Ons moet dit kan verantwoord teenoor die beste empiriese kennis wat vandag beskikbaar is (1 Pet 3:15). Hierdie probleem is natuurlik nie tot die Christelike geloof beperk nie. Ook die ander groot religies werk met aannames wat nie maklik met die bevindinge van die moderne wetenskappe vereenselwig kan word nie. Daar is vanselfsprekend ' $n$ geskiedkundige verband tussen die Joodse, die Christelike, die Islamitiese, en selfs die Marxistiese eskatologie. Die bespreking van die Christelike eskatologie sal dus tot 'n mate ook op hulle van toepassing wees, maar ons kan nie verder daarop ingaan nie.

In die debat tussen natuurwetenskap en geloof word dikwels aangeneem dat die oerknalteorie desnoods met die leerstelling oor die skepping uit niks (creatio ex nihilo), en die evolusieteorie met die voortgaande skeppingsaktiwiteit van God (creatio continua) vereenselwig kan word (ed. Peters 1989:45-113; Russell 2008:33-55). Maar dieselfde geld nie vir die verhouding tussen die entropieteorie en die eskatologiese herskepping van die wêreld nie. Volgens die moderne kosmologie sal die werklikheid soos ons dit ken wel tot 'n einde kom, maar dit sal nie deur ' $n$ nuwe en ideale skepping opgevolg word nie. Russell (2002:3-30, 2008:298-327) het die probleem skerp, amper 'roekeloos' uitgespel.

Soos Russell (2008:298) opmerk, is dit verbasend hoe min aandag hierdie probleem in die hedendaagse debat tussen die natuurwetenskappe en die teologie geniet. Arthur Peacocke (2007), by voorbeeld, is een van die mees vooraanstaande pioniers van die huidige gesprek tussen die fisika en die teologie. In die finale samevatting van sy posisie oor natuurwetenskap en geloof, en die reaksies van tien vooraanstaande kollegas op sy betoog, kom die eskatologie gladnie eers voor nie. In die bykans 1000 bladsye van The Oxford Handbook on Religion and Science is daar slegs drie opeenvolgende bladsye, geskryf deur John Polkinghorne (2006:68-70), wat aan die eskatologie gewy word. Beteken dit dat die eskatologie vir die moderne debat betekenisloos en oorbodig geword het? Dit kan tog nie waar wees nie. Maar Russell (2008:24) se oplossing (natuurwetenskaplike teorieë geld nie noodwendig nie) sal natuurwetenskaplikes nie maklik bevredig nie omdat dit die dogmatiese standpunt nie aan kritiek wil onderwerp nie. Watter ander moontlikhede bestaan daar?

Sauter bied ' $n$ oorsig van die ontstaan en ontwikkeling van die klassieke eskatologie in die Protestantse teologie sedert die sewetiende eeu (Sauter 1996:136-153). Sedert die sogenaamde Verligting is talle teologiese pogings aangewend om die gaping tussen eskatologie en die natuurwetenskappe te oorbrug. In die laaste 50 jaar het daar veral drie hoofrigtings ontwikkel. Die eerste een kan as 'vertikaal' beskryf word. Die woord 'eskatologie' word hier gebruik om die verhouding tussen die gesag van God en die afhanklike en sondige mens te beskryf. God self konfronteer elke mens in elke tydperk van die geskiedenis met sy oordeel en sy moontlike redding. Met hierdie aanname word die hele teologie 'eskatologies' en die begrip het sy oorspronklike betekenis verloor.

Reeds volgens Friedrich Schleiermacher gaan dit by die eskatologie om die verhouding tussen tyd en ewigheid, 'n probleem wat by die Godsleer tuishoort (Sauter 1996:142). Volgens die vroeë Karl Barth openbaar God sy gesag 'vertikaal van bo'. Dit gaan nie om ' $\mathrm{n}$ beter wêreld in die toekoms nie, maar om die ondermynende en herstigtende ontmoeting met God as die Here van die mens (ibid:144). Volgens Rudolf Bultmann word die mens deur God self hier en nou ' $n$ 'ware' bestaanswyse aangebied. Volgens Paul Tillich gaan dit oor die antwoord van die goddelike 'wese' op die dubbelsinnigheid van die menslike geskiedenis. Vir Sauter gaan dit om die 'aankoms' van God in sy belofte en die hoop en motivering wat dit vir die mens in sy haglike geskiedkundige situasie ontsluit (Sauter 1996:146 e.v.; vgl. 171-200).

Die tweede verklaring van die eskatologie kan as 'horisontaal' of 'geskiedkundig' beskryf word. Dit gaan hier om die verwagting van radikale geestelike en maatskaplike veranderinge in die afsienbare toekoms en die verpligting om tot hulle verwesenliking by te dra. Die 'Social Gospel' is 'n vroeë voorbeeld daarvan. Jürgen Moltmann se Theologie der Hoffnung (1966) het op die uitdaging van die neoMarxisme van Ernst Bloch geantwoord. Verskeie vorme van die bevrydingsteologie, insluitende die Latyns-Amerikaanse bevrydingsteologie, Swart teologie en Feministiese teologie, het gevolg. Wolfhart Pannenberg het die vertikale verhouding tussen die transendente God en die immanente werklikheid in terme van die horisontale tydsbegrip verwoord. Hier verskyn God se transendente mag en gesag as die 'mag van die toekoms' (Pannenberg 1989:152). Ook hier het die begrip 'eskatologie' sy oorspronklike betekenis kwyt geraak.

Die derde aanpak konsentreer op die filosofiese kennisleer, die analiese van taalverskynsels, die pluralisme van menslike ervaringsvorme, en die postmodernisme. Die boek van Jackelén (2005) gee 'n goeie indruk van die ingewikkeldheid van hierdie debat. Ek kan net ' $n$ paar aspekte aandui:

- Berus die wetenskap nie ook maar op aannames nie? Is die wetenskapstaal nie ook maar metafories nie? Hoekom moet die teologie as alternatiewe kennisstelsel hom dan aan natuurwetenskaplike kriteria onderwerp?

- Wat is die verskil tussen 'n empiriese (of historiese) feit, wetenskaplike teorie, verslag, mite, saga, legende, gelykenis, en beeldspraak?

- Hoe ervaar die mens so iets soos 'tyd' - as 'n liniêre afloop, 'n siklus, die kwaliteit of die kwaal van die hede, die verskil tussen 'bestaan' en 'wese', of as menslike verhoudings met 'ander'?

Die eskatologie moet al hierdie ervaringsvorme in aanmerking neem. Maar is dit dan nog 'eskatologie'? 
Dit is nie moontlik om in 'n tydskrifartikel op hierdie ontwikkelinge in te gaan nie. Ek wys net daarop dat nie een van hierdie voorstelle die eskatologie van die Bybel of van die klassieke teologie weerspieël nie. Ek beweer ook dat mense wat deur die moderne natuurwetenskappe beïnvloed is, in die algemeen nie beïndruk word deur hierdie pogings om die eskatologie te verklaar nie. Hulle is geneig om uitsprake soos die 'hemelvaart' van Jesus in 'n wolk, of die 'neerdaling van die nuwe Jerusalem uit die hemel' letterlik, dus empiries, te vertolk en dan as vrome fantasie te verwerp. Die geweldige invloed van Richard Dawkins se boek The God Delusion (2006; vgl Nürnberger 2010) wys hoe wyd verspreid hierdie houding in die moderne samelewing is.

Maar selfs gelowiges soos John Polkinghorne, fisikus en teoloog, vertolk Paulus se uitspraak oor die 'geestelike' herskepping van die liggaam letterlik as hy voorstel dat God die 'information-bearing pattern' van ons liggaam na ons dood sal onthou en dan 'n nuwe liggaamlike gestalte sal gee (Polkinghorne 2006:68-70). Robert John Russell, ook fisikus en teoloog, reken dat die opstanding van Jesus die begin van 'n nuwe skepping is wat op nuwe 'natuurwette' gegrond is en wat op die Koninkryk van God sal uitloop (2008:298-327). Indien dit nie kon gebeur nie, sou ons geloof in God in duie stort. Ek is bevrees dat die meerderheid van beide gelowiges en ongelowiges in 'n moderne sameleweing hierdie sienswyse huldig, veral as hulle natuurwetenskaplik ingelig is. Om 'n natuurwetenskaplike vir natuurwetenskaplikes te word (1 Kor 9:19-23) sal ek dus op die letterlike vertolking van tekste in die Bybel konsentreer.

Ek sal eers baie kortliks die uitdaging van die moderne wetenskap vir die tradisionele eskatologie uitspel, dan die Bybelse ontwikkeling van hierdie eskatologie skets, en ten slotte poog om die grondliggende bedoeling van die eskatologie so te verwoord dat dit vandag weer sin kan maak. Ek wil beklemtoon dat hierdie artikel nie bedoel is om ' $n$ bydrae tot die Bybelwetenskappe te lewer nie. Dit is ' $n$ sistematies-teologiese poging om die kern van die boodskap uit sy outydse wêreldbeeld-verpakkings in die terme van die moderne wêreldbeeld te vertaal.

\section{'n Paar insigte van die moderne wetenskap}

In die Bybel kry ons vier projeksies van wat die werklikheid eintlik behoort te wees: na die begin van tyd waar alles baie goed was (Gen 1); na die einde van tyd waar alles goed gaan wees (Op 21); na 'n alternatiewe ruimte (die hemel) waar alles goed is; en na die verborge 'wese' van dinge wat deur God bedoel is om goed te wees. Al vier het binne die geskiedenis van Israel ontstaan as goddelike antwoorde op ongerymdhede en noodsituasies wat ons in hierdie lewe op aarde ervaar. Al vier is in terme van wêreldbeelde uitgespel wat intussen verouderd geraak het. In die lig van die moderne natuurwetenskap het ' $n$ letterlike vertolking van al vier hulle oortuigingskrag verloor:
1. 'n Mitologiese begin van die tyd waar alles 'baie goed' was, word deur die 'oerknalkosmologie' en die ewolusieteorie ondenkbaar gemaak. Daar was, volgens hierdie wetenskaplike teorieë, nog nooit 'n volmaakte wêreld en 'n volmaakte mens wat eers later deur menslike sonde bederf is nie. Die werklikheid as 'n geheel het stadig ontvou en geleidelik al hoe ingewikkelder geword. Die mens het eers heel aan die einde van die kosmiese ontwikkeling opgedaag en sy sonde kon dus nie die ontwikkeling van die werklikheid in sy geheel belemmer nie.

2. 'n Eskatologiese einde van die tyd waar alles 'baie goed' gaan wees, word deur die wet van entropie onmoontlik gemaak. Entropie is die neiging van die werklikheid om van werkkragtige energie na uitgediende energie en van orde na wanorde te beweeg. Alles wat ontstaan, sal ook weer vergaan. Dit geld vir die heelal, vir lewelose objekte, lewende organismes, ons liggaam, ons siel, ons gees, ons gemeenskap en ons betekenisstelsels. Volgens die moderne wetenskap gaan die heelal waarskynlik na ' $n$ verdere paar biljoen jaar tot ' $n$ einde kom. Dit sal òf deur 'n eindelose verspreiding van alle energie gebeur, òf deur 'n geweldige insuiging van alle energie in ' $n$ 'swart gat'. Dit sal egter nie deur ' $n$ volmaakte wêreld vervang word nie. Die kosmiese einde van alle tye sal vir ons mense in elk geval sonder betekenis wees. Nie net die mensdom en alle lewe op aarde nie, maar ook die aarde self en die sonnestelsel as geheel sal teen daardie tyd lankal verdwyn het.

3. Ook ' $n$ alternatiewe ruimte 'in die hemel' waar alles 'baie goed' is, het ondenkbaar geword. Die Rus Gagarin het gespot dat hy in sy Sputnik daarbo nêrens ' $n$ hemel kon kry nie. Toestande in die kosmiese ruimte is nie vir die ontplooiing van lewe geskik nie. Die ontwikkeling van ' $n$ alternatiewe heelal met ander natuurwette sou waarskynlik nie tot die mens as skepsel lei nie. Ons sou in elk geval nie van ons huidige toestand na so ' $n$ alternatiewe wêreld kon beweeg, sonder om ons huidige identiteit te verloor nie.

4. 'n Verborge 'wese' van die werklikheid, soos deur die Platoniese filosofie aangeneem, word ondenkbaar gemaak deur die insig dat die werklikheid aan voortdurende vloei onderhewig is. Nuwe wesens ontstaan, ontplooi, gaan agteruit en vergaan gedurig. Ook die Griekse idee dat daar ' $n$ onsterflike siel in die sterflike liggaam vasgevang is, wat deur die dood bevry word en dan sonder die liggaam sal voortleef, het ondenkbaar geword. Die emergensieteorie sê dat elke hoëre ontwikkelsvlak van die werklikheid op alle laere vlakke berus en nie sonder hulle kan bestaan nie (Clayton [2004] 2006:3-33). Die menslike gees is gestruktureerde bewussyn, wat die werking van die biologiese orgaan van die brein veronderstel, wat weer op chemiese en elektriese prosesse berus en die wisselwerking tussen molekule, atome en partikels veronderstel. Die gees kan dus nie sonder die liggaam bestaan nie.

Die Platoniese idee is natuurlik ook nie van die Bybel afkomstig nie. Vir die Ou Testament en vir Paulus is die 'vlees' die hele mens, liggaam en siel, maar sonder God en dus swak en nietig. Die 'gees' is weer die hele mens, liggaam 
en siel, maar in gemeenskap met God en bemagtig deur God. Geloof beteken dat ons van die lewe in die vlees na die lewe van Christus in die gees skuif. As ons na die dood 'n nuwe lewe gegee word, sal dit volgens Paulus weer 'n liggaamlike, maar tog 'geestelike' soort lewe moet wees (1 Kor 15:35ff.).

Hierdie onversoenbaarheid tussen die apokaliptiese simbool- en beeldspraak aan die een kant en hedendaagse natuurwetenskaplike insig aan die ander is dan die eerste rede hoekom ons huiwerig moet wees om eersgenoemde letterlik te vertolk. In 'n kulturele samehang waar mense die werklikheid deur 'n wetenskaplike bril bekyk - en dit geld feitlik vir almal wat ' $n$ hoërskool besoek het - kan ons maklik ons eie eerlikheid en die geloofwaardigheid van ons boodskap verloor.

Gelowiges het in die geskiedenis van die kerk oor en oor bespotlik geraak as hulle op grond van die simboolgetalle en figuurlike sieninge in Openbaring hulle berekenings gemaak en die einde van die wêreld aangekondig het. Dit het natuurlik nooit gebeur nie en dit is onwaarskynlik dat dit ooit gaan gebeur. Die Bybel is nie ' $n$ boek van goddelike orakels of wetenskaplike voorspellings nie, maar 'n getuie vir die gebroke en herstelde verhouding tussen mens en God. Dit bring ons dan by die tweede rede: die karakter van die Bybelse eskatologiese oorlewering.

\section{Die Bybelse agtergrond}

Dit is duidelik dat die Bybelse toekomsverwagtinge nie eens en vir altyd as omvattende, konsekwente en ondubbelsinnige inligting oor die toekoms 'geopenbaar' is nie, maar as 'n reeks reddende antwoorde op noodsituasies van mense ontstaan en ontwikkel het. Ek verwys in hierdie verband na my eie navorsing (Nürnberger 2002) en die uiteensetting van die ontwikkeling van die eskatologie in die Ou- en Nuwe Testament en die Patristiek deur J. Schreiner, H.E. Lona en B. Daley (Daley, Schreiner \& Lona 1986).

Spesifieke ervarings van redding is in die vorm van soteriologiese tradisies oorgelewer. Abraham het 'n manlike nakomeling nodig gehad, anders sou sy familie uitsterf. Die Israeliete moes van die Egiptiese slawerny bevry word. Die trekboere in die woestyn is ' $n$ vrugbare land belowe. In dié land is die Israeliete deur Filistynse rooftogte geteister en het hulle die sentrale gesag van ' $n$ koning benodig. Babiloniese bannelinge wou huistoe gaan om Jerusalem en die tempel te herbou. Siek en gebreklike mense het by Jesus genesing, sondiges het vergifnis en verstotelinge het aanvaarding kom soek. Paulus het aan mense, wat onder 'n verslawende wet gebuk gegaan het, en diegene wat van die 'volk van God' uitgesluit is, die boodskap van God se reddende aanvaarding van die onaanvaarbare in Christus verkondig.

Die 'Woord van God' is God se reddende antwoord op menslike tekortkominge en noodsituasies. Omdat noodsituasies gedurig verander, het die verkondiging van tradisies oor God se reddende optrede gedurig by die nuwe omstandighede aangepas. Toekomsverwagtinge het in Bybelse tye al hoe wyer horisonne ontwikkel (eers slegs die familie, daarna die stam, die nasie, alle nasies, die ganse aarde, die kosmiese magte en toe die heelal as geheel). Dit het ook geestelik dieper geword (eers die manlike nageslag, daarna 'n land, dan 'n koning, dan 'n nuwe verbond, 'n nuwe internasionale bedeling, 'n nuwe hart, 'n nuwe liggaam, 'n nuwe natuur en uiteindelik 'n nuwe hemel en aarde). Dit het ook inhoudelik verander, soms drasties (Nürnberger 2002). Teen die tyd van die Nuwe Testament was daar 'n groot aantal verskillende tradisies oor die toekoms van God in omloop. Hier is van die belangrikstes:

1. Die voortbestaan van 'n geseënde familie, stam of volk (voorspoed).

2. Die vernuwing van die Sinaïtiese Verbond (verhouding tot God).

3. Die herstigting van die Davidiese koninkryk (nasionale mag en politieke orde).

4. Die groot 'Dag van die Here' (oordeel oor ongelowiges en ongehoorsames).

5. Die Joodse wêreldryk (internasionale heerskappy).

6. Die 'Koninkryk van God' (priesterlike teokrasie).

7. Die 'Seun van die Mens' in Daniël 7 ('n menslike heerser teenoor wrede tiranne).

8. Die seën van die 'Geteisterde Dienskneg' in Jesaja 53 (sinvolle lyding).

9. Opstanding uit die dood vir 'n finale oordeel (God se geregtigheid).

10.Dood en opstanding uit die dood as 'n herskepping van die mens 'in die vlees' tot 'n mens 'in die Gees' (Paulus).

11.Die aftakeling en herskepping van die werklikheid as geheel (apokaliptiese toekomsvisies).

Elkeen van hierdie tradisies het sy eie historiese oorsprong gehad, sy eie wêreldbeeld veronderstel, in verskeie rigtings ontwikkel en in die Jodedom omstrede gebly. Teen die tyd van die Nuwe Testament het sommige eertydse vorms hulle toepaslikheid verloor (manlike nakomelinge, die beloofde land, die tempel in Jerusalem), of hulle het 'n nuwe betekenis gekry (Abraham as vader van die gelowiges; die terugkeer na die land as 'God se rus' in Hebreërs; die messiaanse koning as die gekruisigde Jesus; die nuwe Jerusalem).

Die opstanding van die dode om God se laaste oordeel te ontvang en die apokaliptiese herskepping van die heelal is wel die twee radikaalste en mees omvattende toekomsverwagtinge, maar hulle was deel van 'n hele reeks ander. Hulle verband met die klassieke dele van die $\mathrm{Ou}$ Testament is problematies. Die apokaliptiek maak wel van die motiewe van die ouere profetiese tradisies gebruik. Maar soos die wysheidsliteratuur het die apokaliptiek nie meer in die heilsgeskiedenis van Israel belanggestel nie (Von Rad 1960:316-321). Hulle is in hulle oorspronklike Joodse omgewing dan ook nooit algemeen aanvaar nie. Hulle was ook nie noodwendig oorspronklik nie. Die tradisie van die laaste oordeel het 'n eweknie in Egipte gehad en die ou Perse het geglo dat hierdie wêreld deur ' $n$ nuwe wêreld sonder kwaad vervang sou word. Die Jode het in noue aanraking met hierdie kultuurgroepe geleef en hulle het heel waarskynlik die Joodse denke beïnvloed. 
Die eerste Christene het wel apokaliptiese verwagtinge gekoester. Maar toe die verwagte wederkoms van Christus 'op die wolke' nie plaasgevind het nie, het die verkondiging op 'n veranderde geestelike situasie geantwoord. Reeds in Nuwe-Testamentiese tye het die klem van 'toekomstige eskatologie' na 'n 'teenwoordige eskatologie' verskuif. Volgens Romeine 6:1-11 'sterf' ons nou reeds met Christus om met hom te lewe. In Efesiërs 1:20-23; 2:1-6 en Kolossense 1:15-20; $2: 9-15$ is Christus nou al die wêreldheerser en ons is saam met hom opgewek en hemel-toe. In Hebreërs 2-10 is Christus nou reeds die Hoëpriester. In Johannes 3:17 en 5:24 vind die laaste oordeel nou reeds plaas. Christus het oënskynlik anders gekom as wat oorspronklik verwag is, naamlik in die vorm van die 'Gees' van Christus wat die 'Liggaam van Christus' bevry, vernuwe en met gesag vir sy sending toegerus het (1 Kor 12-14).

Die vraag onstaan dan hoekom die hedendaagse teologie verplig moet voel om enige van die historiese toekoms verwagtinge as blywend geldig en toepaslik te beskou, veral as hulle hul oorspronklike bedoeling en funksie al duisende jare gelede verloor het. Die gevaar is dat ons in die verlede vasgevang word en die toekoms verloor. Ons moet besef dat dit die kragtige en dinamiese boodskap van God se skeppende en reddende liefde is wat al hierdie tradisies in hulle tyd voortgebring, gebruik en ook weer agtergelaat het om telkens nuwes te vorm. Is die verkondiging van die opstanding van die dode so ' $\mathrm{n}$ tradisie wat agtergelaat kan word? Kom ons kyk.

\section{Opstanding van die dood}

Die motief van die opstanding van die dood het eers taamlik laat by die Joodse teologie ingang gevind. Ons kry dit nie in die klassieke geskrifte van die Ou Testament nie. Laasgenoemde vertoon ' $n$ verbasend realistiese beoordeling van die dood as onvermydelike einde van die lewe (Jes 26:14; Ps 6:5, 88:10ff; Job 7:9ff.; 14:1-22). 'n Uitstekende oorsig word deur Wolff (1974:150-176) aangebied. Vergelyk ook Jüngel ([1971] 1973:75-103) en Wilckens (1970:103-114). Mense wat gesterf het, is afgesny van die seëninge van God en die lofprysing van God. Selfs nog in die boek van Sirag, wat gewoonlik as tussen 180 en 175 voor Christus gedateer word, word gesê dat die dood op 'n onveranderlike dekreet van God berus en dat ons maar daarmee moet saamleef (Sirag 17:1-2, 27-28; 41:1-4). Die motief het dan ook nooit ingang onder al die Jode van daardie tyd gevind nie en was selfs in Jesus se tyd nog omstrede (Mark 12:18).

Die vroegste verwoording van die verwagting dat mense uit die dood gaan verrys om vir hulle dade vergoed of bestraf te word vind ons in Daniël 12:1-4, wat gewoonlik tussen 168 en 164 voor Christus gedateer word. Die strekking van hierdie teks is eties en sy verwoording mitologies-apokalipties. Die etiese kern van die saak word ook in die Wysheid van Salomo duidelik. In felle kontras met Sirag staan dit vir die opstanding en die laaste oordeel in en beweer dat sy loënaars net maar vry wil wees om 'n roekelose lewe te lei (1:12-3:19). Vir Sirag geld dit natuurlik hoegenaamd nie.

\section{Op watter probleme het dit geantwoord?}

Die verwagting dat die dooies gaan verrys het oënskynlik twee geskiedkundige wortels gehad. Die eerste was die kwellende vraag hoe ' $n$ magtige en liefdevolle God so baie kwaad en lyding in die wêreld kon toelaat. Hierdie probleem word in die teologie 'teodisee' genoem. 'n Diepgaande bespreking van dié probleem in die Ou Testament word in Brueggemann (1997:359-399) gevind. Die verkondiging van Deuteronomium 28 en 30 het gesê dat wetsgehoorsaamheid tot seën en ongehoorsaamheid tot vervloeking lei. Maar dit het nie noodwendig so gebeur nie. Die goddelose mense (veral die heidense onderdrukkers) het die lewe geniet en gesterf sonder om gestraf te word, terwyl godvresende mense gesukkel en gesterf het sonder om beloon te word. Dit het die geweldige geestelike worstelinge veroorsaak wat ons dikwels in die Psalms kry (Ps 10; 37; 73; 82:8; 94:3 e.v.; ens. vgl. Jer 12:1-4 en Job 21:7). Soos die lyding onder een imperiale moondheid na die ander toegeneem het, het die kwelling in die Jodedom na die ballingskap toenemend ondraaglik geword.

Dit is opvallend dat die laaste oordeel in die Bybel altyd betrekking het op wat ons in hierdie lewe aangevang het, nooit op wat ons na die dood miskien sou kon regkry as ons in ' $n$ nuwe lewe sou verrys nie. Die klem val dus nie op ' $n$ eindelose lewe in die hiernamaals nie, maar op die geldigheid van God se aanspraak op menslike geregtigheid in hierdie lewe - en dit ten spyte van die feit dat ons almal die dood tegemoet gaan. Ook volgens Daniël 12:2-4 sal die resultaat van die opstanding wees dat sondaars in eindelose en afgryslike skande gaan beland en die verstandiges sal 'glinster soos die glans van die sterre'. Hier val die klem op ons etiese status voor God.

Die motief van die opstanding van die dode het dus as versekering van God se getrouheid en geregtigheid gedien. 'In die Joodse denke staan die vraag na die opstanding in die samehang van die vraag na die teodisee' (Wilckens 1970:115 - my vertaling). God sal die goddelose straf en die regverdige beloon. Die gehoorsame mens gaan nie deur nood of onderdrukking oorweldig word nie. Sondaars sal hulle oordeel nie ontsnap nie en gehoorsames sal hulle seën nie verbeur nie. Die gedagte word dikwels tot uiterstes gedryf: niemand kan God se aanwesigheid en geregtigheid ontsnap nie, al bevind hy hom ook in die doderyk (Ps 139:8), en niemand wat regverdig is kan van God vervreemd raak nie, al kwyn sy liggaam en hart (Ps 73:21-24).

'n Tweede wortel van die motief was dat mense in die antieke wêreld 'n oorsaaklike verband tussen die sonde en die dood vermoed het. Die geestelike en die biologiese aspek van die lewe is nie altyd noukeurig onderskei nie. As God die Skepper van die lewe is, kan jy nie bly lewe as jy van God vervreemd raak nie. As net maar die sonde oorkom kon word, sou die dood ook sy mag moes verloor. Dit is immers God wat dood maak en lewendig maak (1 Sam 2:6; Deut 32:39). Volgens hierdie redenasie is die mag van die dood dus die gevolg van die sonde (Rom 5:12; 8:6; 1 Kor 15:56; Jak 1:15). Dit sal saam met die sonde oorwin word (1 Kor 15:26, 56). Die 
opstanding van die dode word dan verstaan as die herstel van ware menslike lewe sonder sonde in gemeenskap met God (Rom 6:8-10; 21-23). Christus het gesterf omdat hy die mens se sonde op hom gelaai het, en sy opstanding het dit vir gelowiges moontlik gemaak om aan sy lewe in geregtigheid deel te hê.

Hierdie gedagte is sinvol as dit figuurlik vertolk word, soos dit in Romeine 6:1-23, Efesiërs 2:1-10 en 1 Johannes 3:14 gedoen word. Johannes 1:12 en 3:3-8 maak van die beeldspraak van wedergeboorte gebruik om dieselfde waarheid te verwoord. Dood is verwydering van God, lewe is vereenselwiging met God. Dit gaan in elk geval om 'n gesonde verhouding tussen Skepper en skepsel. Maar as ons hierdie beeldspraak, of dit nou 'opstanding' of 'wedergeboorte' is, letterlik-biologies wil vertolk, maak dit nie meer sin nie. Die ligaamlike dood is nie ' $n$ gevolg van die sonde nie, maar ' $n$ biologiese noodsaaklikheid. Alle mense moet sterf, of hulle nou onberispelike heiliges of kwaadaardige sondaars was. Die biologiese dood is ingebou in die werklikheid van die lewe wat God geskape het, en kan as sodanig nie 'oorwin' word nie. Alle lewende wesens sterf. Die onderliggende motief is dus ook nie ' $n$ wetenskaplik verantwoordbare verklaring van wat na die dood gaan gebeur nie, maar die daarstelling van 'n gesonde verhouding tussen die mens en God.

\section{Die 'ewige lewe'}

Die idee van 'n tydlose 'ewigheid' kry ons nie in die Ou Testament nie. Die Hebreeuse woord wat gewoonlik met 'ewigheid' vertaal word (ad olam) beteken so iets soos 'in die onafsienbare toekoms.' Dit verwys gewoonlik na die betroubaarheid van God se verhouding tot sy volk. God se tyd is nie deur die mens se lewenstyd beperk nie. God se genade oorkom menslike sonde. Sy genade duur voort deur die opeenvolgende geslagte. Soos reeds vermeld, het die Griekse filosofie probeer om 'n tydlose 'wese' uit die vloei van die tyd te abstraheer. Maar ' $n$ abstraksie van die werklikheid is self nie werklik nie. Selfs die wortel van die Griekse woord vir 'ewigheid' (aion) het die betekenis van 'die hele tydvak' of 'al die tyd'. Volgens die Ou Testament is die mens ' $n$ skepsel en alle skepsels is sterflik. Die mens se lewe word deur God gegee en weer deur God ontneem (Gen 3:19). Slegs God is onsterflik. Die Nuwe Testament verander geensins hierdie siening nie (1 Tim 6:16). Indien die mens na sy of haar dood weer ' $n$ nuwe lewe geskenk sou word, dan sou dit sekerlik nie die soort lewe wees wat ons nou leef nie (1 Kor 15:35 e.v.).

Maar 'ewige lewe' is nie ' $n$ eienskap wat sterflike mense ooit kan besit nie. Die Bybel is in hierdie opsig uiters realisties. Ewige lewe kan slegs ons deelname aan 'God se lewe' beteken. Van God se lewe ken ons slegs sy skeppingskrag, sy reddende liefde en sy visie van omvattende welsyn vir ons ervaarbare werklikheid. Jesus se verkondiging, handelinge en dood aan die kruis het 'God se lewe' as 'n lewe van opofferende liefde openbaar. Dit is ons deelname aan hierdie offervaardige liefde van God wat ons lewe 'n betekenis en waardigheid gee wat bo ons tydelikheid en sterflikheid uitstyg.

Hoe gebeur dit? Volgens Paulus is die verrese Christus die voortgesette aanwesigheid van die Gees van die gekruisigde Christus (1 Kor 1:23) in die Liggaam van Christus, die gemeenskap van gelowiges (1 Kor 12-14). Jy kan die verrese Christus slegs konkreet beleef waar mense in die moed, die krag en die liefde van die gekruisigde Jesus leef en handel. Volgens Paulus lewe ons nie meer 'volgens die vlees' nie, dus nie meer vir ons self nie, maar vir Christus wat vir ons gekruisig is (2 Kor 5:15).

Dit wil sê ons leef nou 'in Christus' of 'in die Gees', nie meer in die selfsug van die 'vlees' nie (Rom 8:1-13). Ook Christus wil Paulus nie meer 'na die vlees' ken nie (2 Kor 5:16-17). Volgens Johannes sal Christene wil wees waar Christus is en dit kan net in sy opoffering vir ander wees (Joh 12:25 e.v.; 14:3 e.v.). Ons deelname aan Christus se nuwe lewe, dus aan God se lewe, is 'n deelname aan God se liefde (1 Joh 4:7-21).

\section{Die Middeleeue}

Die teologie het vervolgens geantwoord op die Hellenistiese wêreldbeeld. Die impak van die Platoniese denke op die Christelike begrip van die dood en die teologiese taak om daarvan afstand te doen word deur Jüngel ([1971] 1973:57-74) verduidelik. Die klem het nie meer op ' $n$ beter toekoms geval nie, maar op 'n verlange na 'tydlose waarheid'. Die Griekse idee van 'n onsterflike siel wat van die sterflike liggaam verlos moes word, het die Hebreeuse begrip van die eenheid van liggaam en siel vervang. Omdat dit deel van die Bybelse kanon was, kon die tradisies van die apokaliptiese herskepping van die werklikheid, die wederkoms van Christus op aarde en die opstanding van die liggaam nie eenvoudig prysgegee word nie, maar het dit van 'n onmiddellike verwagting na die verre toekoms geskuif. Dan sou die onsterflike siel weer met sy verrese liggaam herenig word.

Die Romeinse siening van gesag en wet het weer die ontwikkeling van die kerkstruktuur bepaal. Die Katolieke gesag is op die Romeinse imperiale stelsel geskoei. Die hiërargie onder die pous het in alle belangrike opsigte die verwagte 'koninkryk van God' vervang. Die klem van die eskatologie het op die laaste oordeel en sy dubbele uitkoms geval: ewige geluk in die hemel, of ewige pyn in die hel. Die gesag van die apostels om sonde te vergewe, is so vertolk dat die priesterlike hiërargie die mag gehad het om die genade van God soos handelsware in ruil vir die vervulling van sekere voorwaardes of voorgeskrewe betalings uit te deel.

Drie onversoenbare tradisies - Joods, Grieks en Romeins - is dus met mekaar verbind en hierdie dogmatiese konstruksies het aanvaarde ortodoksie geword. Dit het tegelykertyd 'n bron van eindelose spekulasie, konflik en twyfel geword. Sulke ontwikkelinge vind plaas as tradisies wat nie meer by die nuwe situasies pas nie, as ewige Woord van God misverstaan en voortgesit word. 


\section{Was dié tradisies ooit bedoel om letterlik vertolk te word?}

In terme van hedendaagse wetenskaplike insig is die letterlike vertolking van die eskatologiese verwagtinge onrealisties. Die vraag is egter of hulle ooit bedoel was om letterlik verstaan te word. Antieke dokumente was nie onderworpe aan die moderne kriteria van empiriese bewysbaarheid en historiese juistheid nie. Skrywers het hulle geërfde tradisies vryelik verander, korter gemaak, of aangevul om hulle boodskap by nuwe situasies aan te pas. Vergelyk net die 'eskatologie' van die Johannes-Evangelie met dié van Openbaring! Hulle het ook al die taalmiddele tot hulle beskikking gebruik om die skeppingskrag en die reddende liefde van God te verkondig - mites, legendes, sages, verhaalkuns, digkuns, gelykenisse, beeldspraak, en droombeelde. Hulle wêreld was vol engele, demone, monsters, sterrebeelde en wonderwerke.

Onder ongeletterde mense is die verskil tussen metafoor en empiriese werklikheid nie altyd baie duidelik nie en die oorgang van 'feit' na bygeloof is redelik vloeibaar. Maar die beeldspraak van baie van hierdie toekomsverwagtinge kan selfs deur die onopgeleide leser skaars oor die hoof gesien word. Bybelse skrywers maak dikwels gebruik van die hiperbool as 'n stylfiguur: berge gaan verlaag en valleie gaan opgevul word (Jes 40:4); leeus gaan gras vreet en wolwe en lammers sal saam wei (Jes 11:6-7); die son en maan gaan hulle lig verloor (Joël 3:15); arm mense sal uit die ashoop opgehef word om die eer van prinse te deel (Ps 113:7-8); ' $n$ sterk geloof sal berge in die see kan laat stort (Mark 11:23). Sommige profetiese uitsprake oor die oorwinning van die dood en 'n nuwe wêreldorde val onder hierdie kategorie (Jes 25:6-10).

Maar die apokaliptiek gaan verder. Dit is ' $n$ tipiese karaktertrek van apokaliptiese visies dat hulle 'n onrealistiese en simboliese beeldspraak gebruik. Ons lees van monsters, geheimsinnige getalle, bonatuurlike natuurverskynsels en hemelse engelmagte. Dit was waarskynlik 'n soort geheime, en waarskynlik doelbewus geheimsinnige taal wat bedoel was om gelowiges onder hewige vervolging nuwe moed in te boesem. Die verkondiging van 'n radikaal onwaarskynlike verandering het na God se alles-oorheersende mag en welwillendheid verwys.

Kyk maar net na die beskrywing van die nuwe Jerusalem in Openbaring 21. Die stad sou van die hemel neerdaal as ' $n$ volmaakte kubus. Sy lengte, hoogte en breedte sou elk 2400 kilometers beslaan. Die stad sou van suiwer goud wees, maar nogtans deurskynend soos glas, met twaalf hekke, elk van 'n enkele juweel gemaak. Dat ons hier met bewuste beeldspraak te doen het, is ooglopend. Openbaring maak ook vryelik gebruik van simboliese getalle. Ontsettend baie onsin is deur mense veroorsaak wat hulle letterlik histories probeer verklaar het.

Metaforiese taalgebruik vind ons ook in die verhale oor die verskyning van die verrese Christus. Hy kon normale kos eet en praat soos ' $n$ fisiese persoon, maar nogtans deur geslote deure beweeg (Luk 24:36-43; Joh 20:19-23). Hy kon skielik verskyn en weer verdwyn (Luk 24:15-31). Hy was so anders dat hy selfs nie deur sy dissipels herken is nie (Luk 24:31; Joh 20:14), maar tog was sy wonde sigbaar en tasbaar (Joh 20:27). Hy is in ' $n$ wolk in die hemel opgeneem en sit 'aan die regterhand van God' (Hand 1:9; Mark 16:19), en tog is hy teenwoordig waar twee of drie in sy naam vergader (Matt 18:20), of waar die dissipels met hulle sending besig is (Matt 28:20). Is hierdie beskrywings beeldspraak wat ' $n$ geestelike waarheid verwoord, of het dit alles letterlik so gebeur?

Vir ' $n$ histories-kritiese siening is dit duidelik dat die legendariese verhale oor die verskyning van die verrese Christus oor tientalle jare in uiteenloopende rigtings ontplooi het. Daar is ' $n$ tydelike afstand van omtrent 25 jaar tussen die gebeure self en die oudste samevatting van oorlewerings oor die opstanding wat ons het (1 Kor 15:3 e.v.). Daar is weer ' $n$ historiese afstand tussen Paulus se verhaal en die Evangelies, en ook tussen die verskillende Evangelies. Die ontploiing van die legendes het ook daarna nog voortgegaan soos die verhaal in die sogenoemde Petrus-evangelie bewys.

Hierdie verhale het in antwoord op verskillende situasies ontwikkel en kan dus ook nie meer met mekaar vereenselwig word nie (Wilckens 1970:12-17). Het sy sending-bevel op 'n berg in Galilea, of in ' $n$ geslote kamer in Jerusalem gebeur? Was Petrus die eerste getuie, of was dit sekere vrouens by die graf? Hoeveel en watter vrouens? Het sekere dissipels saam met die vrouens die leë graf gesien? Was hulle te bang om iets te sê, of is hulle met vreugde daar weg om die dissipels in te lig? Het die vrouens se getuienis die manlike dissipels oortuig of nie? Kon hy betas word of nie? Hoekom is hy dikwels selfs deur sy dissipels nie dadelik herken nie? Die bronne gee op elk van hierdie vrae weersprekende antwoorde. Hans Gras ([1956] 1961) en Ulrich Wilckens (1970) het hierdie tradisies aan baie noukeurige geskiedkundige en eksegetiese ondersoek onderwerp.

\section{Teologiese probleme}

Daar is ook teologiese probleme wat myns insiens die letterlike vertolking van dood en opstanding en die apokaliptiese wêreldbeeld in 'n Protestantse konteks problematies maak. Dit word nie baie dikwels aangespreek nie. Die apokaliptiek beweer eintlik dat God tou opgooi en nie meer kans sien om met die vernuwing van sy skepping te sukkel nie. Hy sou sy mislukte mens en sy mislukte wêreld vernietig en 'n perfekte mens in 'n perfekte wêreld skep. Dit beteken dan ook dat die ou mens en die ou wêreld eintlik niks werd is nie. Die laaste oordeel, of dit nou by die mens se sterwe of lank daarna sou gebeur, is daarmee as onafwendbaar en finaal verklaar. Daar sou dan geen genade meer kon wees nie. Die wêreld as geheel is as reddeloos beskou. Dit moes vernietig word en deur iets anders vervang word.

Hoe klop dit nou met die reënboog-verbond van Genesis 9:8-17? Die God wat ons deur 'n verskeidenheid van Bybelse toekomsverwagtinge leer ken het, is nie 'n God wat tou opgooi en sy volk of sy skepping laat vaar nie. Ook in die $\mathrm{Ou}$ 
Testament gee God sy mense altyd weer 'n kans; hy verlang altyd na hulle redding; hy maak altyd weer die toekoms vir hulle oop. In die bevrydingsteologie is die tradisionele eskatologie dikwels as ' $\mathrm{n}$ 'pie in the sky when you die' gekritiseer. Dit is hierdie aarde wat vernuwe moet word; die hunkering na 'n perfekte hiernamaals mislei die mens net.

Hoe klop dit met die verkondiging van God se vergewende en vernuwende genade in Christus, wat tog vir Protestante die 'artikel is waarmee die kerk staan of val'? Jesus se vertolking van die God van Israel as 'n God van onvoorwaardelike ontferming oor die sondaar het hom immers aan die kruis laat beland. Glo ons dus aan 'n God wat almal sal verpletter wat nie volmaaktheid kon bereik nie, of glo ons aan 'n God van barmhartigheid?

Die evangelie nooi ons om aan God se opofferende liefde in Christus deel te hê. Dit moedig ons aan om nie oor ons eie oorlewing, voorspoed en eindelose lewe bekommerd te wees nie, maar om ons lewe vir die redding en voorspoed van ander mense te gee, soos Christus gedoen het (1 Joh 3:16). Om jou eie belang te verloën en in Christus se liefde te bly beteken 'ewige lewe' (Joh 15:9-13; 12:24-26). Die behebdheid met jou eie ewige heerlikheid en geluk gaan presies in die verkeerde rigting. Jy soek jou eie voordeel, in plaas van die welsyn van God se wêreld. Jy doen net goed om uiteindelik deur God beloon te word.

Daar is wel talle tekste in die Bybel wat ' $n$ mens so kan verstaan, maar dit strook nie met die kruis van Christus nie en dit is die kruis wat die verrese Christus definiëer (1 Kor 1:23). Dit strook eerder met die moderne kultuur van onbeperkte hebsug en genotsug. Teen die agtergrond van die ekonomies-ekologiese krisis het die herwinning van offervaardigheid in die Gees van Christus ' $n$ dringende noodsaaklikheid geword.

Die Bybelse toekomsverwagtinge kan dus soos volg saamgevat word: Dit is God se dinamiese visie van omvattende welsyn vir God se skepping as geheel. Dit lei tot God se besorgdheid (en dus ons besorgdheid) oor enige gebrek aan welsyn in enige aspek van die lewe. Dit plaas die klem op maatskaplike regverdigheid en liefdevolle sorg vir die lydende en kwesbare medemens. Dit verander gedurig soos 'n horison wat vorentoe beweeg soos ons dit nader. Dit openbaar altyd nuwe gesigspunte, uitdagings en geleenthede.

\section{'n Eietydse vertolking van eskatologiese motiewe}

Wat doen ons nou - kan ons nie die uitgediende toekomsverwagtinge van twee duisend jaar gelede eenvoudig oorboord gooi nie? Nee, dit sou 'n onverskillige gevolgtrekking wees. Ons moet die onderliggende bedoeling van hierdie tekste ontdek en in ons huidige denkwyse vertaal. Dit is immers wat die Bybelse skrywers self gedoen het. Ons moet dus vir ons eie tyd doen wat ons ouers in die geloof vir hulle tyd gedoen het. Om dit te kan doen, moet ons die grondliggende stukrag van die Woord van God ontdek wat tot die groot verskeidenheid geskiedkundig ingesetelde vorms gelei het, naamlik die skeppende en reddende liefde van God, soos dit in Christus finale beslag gekry het. Ons kan maklik die volgende eskatologiese motiewe onderskei soos hieronder bespreek.

\section{Die opstanding van Christus}

Oorspronklik het die boodskap van die opstanding van Christus 'n dubbele strekking gehad:

1. God het deur die opstanding bevestig dat Jesus van Nasaret in die gesag van God gehandel het toe hy die God van Israel as ' $n$ God van reddende genade (teenoor 'n verdoemende wet en kultiese reinheidsvoorskrifte) verkondig en uitgeleef het. Sy Joodse vyande het gemeen dat God met die dood van Jesus sy veroordeling op grond van kettery en godlastering bevestig het. Die Christene het darenteen verkondig dat God hom as die messiaanse verteenwoordiger van God bevestig het:

Dat God homself met die gestorwe Jesus geïdentifiseer het, is die fondament van die geloof in Christus wat deur die geloof self veronderstel word ... (waardeur) God homself vir die geloof allereers as die ware God gedefiniëer het. (Jüngel [1971] 1973:137 - my vertaling).

Dit is die kern van die konflik waaroor dit in daardie tyd gegaan het.

2. God het die nuwe menswees in gemeenskap met God, wat in Jesus as 'n enkele persoon in ' $n$ sekere geskiedkundige en kulturele samehang werklikheid geword het, vir alle mense ten alle tye en in alle situasies geldig en toeganklik gemaak. Hy 'sit aan die regterhand van God' en God is orals. Volgens Paulus is die verrese Christus identies met die Gees van Christus wat die Liggaam van Christus, die gemeente van gelowiges, deurdring, vernuwe en gebruik vir sy opofferende en reddende liefde (1 Kor 12-14; Ef 2:13-22; 4:1-16). Hy is die nuwe Adam wat die ou Adam vervang het (Rom 5:12-21; 2 Kor 5:14-17). Hy is die ware 'beeld van God' in wie se beeld ons omskep word (2 Kor 3:18; 4:5; Kol 1:15).

Hierdie waarheid word in die Nuwe Testament ook vervat in die beeldspraak van Christus as messiaanse koning van die koninkryk van God, of die herder wat deur sy skape gevolg word, of die wynstok wat sy takke vrugte laat dra, of die liefde van die Vader wat in die Seun en die liefde van die Seun wat in die gelowiges posgevat het en daar moet 'bly'.

\section{Die apokaliptiese herskepping van die werklikheid}

Die apokaliptiek verteenwoordig 'n radikale en bewustelik metaforiese verwoording van God se visie van omvattende optimale welsyn van die mensdom binne die omvattende welsyn van sy sosiale en natuurlike samehange. Om sy geloofwaardigheid vir ons tyd te herwin, moet hierdie visie weer grond vat. Wat behoort te wees, moet weer soos in die Bybel afgelei word van die ervaring van wat nie behoort te wees nie. Dit moet weer op die afsienbare toekoms betrekking hê. Dit moet ten minste in beginsel haalbaar wees as mense maar net van hulle eiesugtige denke en gedrag afstand wou 
doen en aan die skeppende en reddende liefde van God wil deel hê. Dit moet rigting en oortuigingskrag gee vir die doelwitte en handelinge van mense in hulle alledaagse lewe, hulle gemeenskaplike omgang, hulle maatskaplike vorme en hulle houding teenoor die natuur.

Eietydse voorbeelde kan maklik gevind word: 'n gesonde en sinvolle lewe vir elke mens; gesonde menslike verhoudinge; ekonomiese toereikendheid en regverdigheid; gemeenskaplike en maatskaplike vrede, en ekologiese gesondheid. Teen die dinamiese agtergrond van Bybelse toekomsverwagtinge kan hierdie visie verstaan word as ' $n$ horison wat gedurig vorentoe skuif soos ons hom nader en wat telkens nuwe gesigspunte,uitdagings en geleenthede openbaar en sodoende rigting gee aan ons konkrete, sosiale, gemeenskaplike, geestelike en etiese lewe.

\section{Die algemene opstanding van die dode}

Hierdie motief het geantwoord op die vraag of die sondaars ongestraf gaan bly en die gehoorsames hulle loon gaan kwyt raak net maar omdat hulle sterf. Dit het ook geantwoord op die vraag hoe die sondige mens deur die handeling van God tot ' $n$ regverdige mens omskep kan word. Hoe kan ons hierdie gedagte binne die raamwerk van die moderne wetenskap verwoord? Ek wil twee aspekte uitlig - 'n inhoudelike en 'n formele een.

Soos reeds gesê, pas die menslike verlange om die eie lewe eindeloos voort te sit, inhoudelik nie alte goed by die selfskenkende liefde van God wat hom aan die kruis van Christus openbaar het nie. Christus het immers nie vasgeklou aan sy lewe nie (Joh 12:24 e.v.). Die opstanding van Christus het juis hierdie soort lewe en sterwe tot die voordeel van ander algemeen geldig en toeganklik gemaak sodat dit ook in ons ' $n$ werklikheid kan word. Geloof in Christus beteken deelname aan Christus se nuwe lewe in gemeenskap met God in die krag van die Heilige Gees.

Die formele aspek kan miskien soos volg verwoord word. Die lewe van elke mens - as lewe met ' $n$ afsonderlike bewussyn - beslaan 'n onbeduidend klein deeltjie van die kosmiese geskiedenis, net soos die aarde ' $n$ nietige stofkorreltiie in die heelal is. Maar elke lewe het voortgespruit uit 'n kolossale netwerk van oorsake wat in beginsel tot by die oerknal teruggevoer kan word. Dit sit ook voortdurend 'n ewe kolossale netwerk van gevolge aan die gang wat ten minste tot die einde van alle lewe op aarde sal voortgaan. Die vraag is dus watter soort effek ons lewe op die werklikheid as geheel gehad het.

Teologies gesproke is God se lewe, dus God se liefde, die enigste lewe wat 'ewigheid' kan hê. My individuele bewussyn het uit die skeppende projek van God voortgespruit en sal weer met die skeppende projek van God saamsmelt. Soos alle lewe op aarde sal dit na my dood 'n deel van die verlede geskiedenis word. Dit sal eenmaal ontstaan en ontplooi, en ook weer agteruitgegaan en vergaan het. As sodanig is dit die resultaat van God se liefde. Die 'laaste oordeel' gaan oor watter soort gevolge ons lewe vir God se projek voortgebring het. Was dit 'n werktuig van God se skeppende en reddende liefde, of het dit God se doelwitte ondermyn en belemmer (Matt 25:31-46)?

Die evangelie sê dat God se genade ook ons mislukte lewens nog kan regmaak en gebruik vir sy doel. Dit kan egter net gebeur as God ons sonde in sy gemeenskap verduur en oorkom. Dit is immers wat vergifnis beteken: God aanvaar ons alhoewel ons nie vir hom aanvaarbaar is nie. In Christus ly God onder ons sonde om dit van binne sy gemeenskap te oorwin. Daarom is die eenmaligheid, waardigheid en kosbaarheid van ons lewe nie aan ons eie morele voortreflikheid, biologiese lewenskrag of hoë geestelike gesteldheid toe teskryf nie, maar aan ons deelname aan die 'lewe van God', dus aan sy skeppende en reddende liefde.

As ons dus in 'vrede met God' leef, kan ons ook in vrede sterf. Ons kan ons lewe aan die einste God oorhandig wat dit by ons geboorte aan ons toevertrou het, en wat dit intussen op menigvuldige wyse geseën, bevry, hernuwe en toegerus het. As ons in God se lewe gedeel het, sal ons lewe nooit vir God betekenisloos kan word nie. Dit sal altyd deel bly van die oerkoepelende lewe van God omdat dit deel is van die wêreldproses as 'n geheel wat die skeppende krag en die offervaardigheid van God vir sy skepping weerspieël. Wat hierdie vertroue te bowe gaan, beweeg in die doolhof van spekulasie. Jüngel (1973) het dit as volg gestel:

Die Bybelse begrip van die Skepper behels aan die kant van die skepsel inderdaad beide begin en einde. ' $n$ Einde verskil van ' $\mathrm{n}$ aftakeling teologies gesproke daardeur dat op ' $\mathrm{n}$ aftakeling niks volg nie, sodat anderkant die aftakeling net nog die niks is, die afwesigheid van wat afgetakel is, terwyl op die einde God volg, sodat anderkant wat beëindig is, nie die niks is nie maar dieselfde God wat aan die begin was (bl. 115 [my vertaling]; vgl. ook bl. 148-154).

\section{Die kosmies-omvattende geldigheid van die evangelie}

Tot sover die persoonlike aspek. Wat van die kosmiese aspek wat deur die apokaliptiek aangespreek word? Die evangelie van God se lydende, vernuwende aanvaarding van die onaanvaarbare (die 'regverdiging van die sondaar uit genade en nie op grond van sy eie prestasie of goedheid nie' Ef 2:8-9) moet uit sy noue betrekking met die individuele mens uitgelig en op die werklikheid as geheel toegepas word. Die wet van entropie maak ons oë oop vir die feit dat God die hele tyd besig is om dele van sy skepping op te offer sodat ander dele, vorme en prosesse van die werklikheid moontlik kan word.

Die vernietigende uitwerking van die entropiese proses is nodig om energie aan die wêreldproses te verskaf. Atome gee hulle eienskappe prys as hulle tot molekule verbind word. Die vernietigende uitwerking van die dood is nodig 
om voortgaande lewe moontlik te maak. Dit geld vir die metabolisme binne liggaamselle, die verhouding tussen selle binne organismes, en ook die verhouding tussen organismes en die opeenvolging van organismes binne spesies. Minerale word uit 'sterwende' sterre gebore; vrugbaarheid ontstaan uit kompos; mense kan slegs lewe as hulle ander lewe verteer. 'Tensy die koringsaad in die grond val en vergaan bly dit alleen; maar as dit vergaan dra dit baie vrug' (Joh 12:24). Wat hier van Christus gesê word is tegelyk 'n onafwendbare beginsel van die wêreld as geheel soos ons dit ken en soos God dit geskape het. As God ons in sy gemeenskap aanvaar, nooi God ons om aan hierdie opofferende aktiwiteit deel te neem. Hierdie insig is van onskatbare betekenis vir ons houding teenoor die teenwoordige ekonomies-ekologiese krisis (Nürnberger 2011).

God se skeppingskragtige en reddende aktiwiteit omvat die kosmiese geskiedenis vanaf die oerknal (big bang) tot by die uiteindelike ineenstorting (big crunch), of dan die totale verspreiding van energie. Alle vlakke van die werklikheid die heelal, die melkweg, die sonnestelsel, die aarde, lewe op aarde, die mensdom, en die kortstondige lewe van die enkeling - is almal ingebed in die oorkoepelende samehang van die skeppingskragtige en reddende 'lewe van God'.

Wat ons van hierdie 'lewe van God' weet en ooit sal kan weet, is (1) die konkrete wêreldproses wat ons ervaar en wat die wetenskappe ondersoek, en (2) die verkondiging van die Bybelse tradisie dat God se skeppende mag en liefderyke doelstelling die dryfkrag agter die werklikheid is wat ons in die geloof aanvaar. En die ontstaan en ontplooiing van die Bybelse tradisie is self deel van die ewolusionêre proses.

\section{Slotsom}

Hierdie vertolking pas by die dinamiese karakter van die toekomsverwagtinge in die Bybel, sonder om huidige wetenskaplike insigte oor die oorsprong en einde van die heelal, die lewe in die algemeen en die menslike lewe in besonder te weerspreek. Dit is dus heel moontlik om die strekking van die eskatologiese boodskap in die Bybel in denkwyses te vertaal wat vir die moderne mens sin kan maak, sonder om die bedoeling prys te gee wat dit oor meer as 'n duisend jaar van Bybelse geskiedenis ontwikkel het.

\section{Erkenning Mededingende belange}

Die outeur verklaar dat hy geen finansiële of persoonlike verbintenis het met enige party wat hom nadelig kon beïnvloed in die skryf van hierdie artikel.

\section{Literatuurverwysings}

Brueggemann, W., 1997, Theology of the Old Testament: Testimony, Dispute, Advocacy, Fortress Press, Minneapolis, MN.

Clayton, P., [2004] 2006, Mind and Emergence: From Quantum to Consciousness, Oxford University Press, Oxford.

Conradie, E., 2006, Lewe anderkant die dood?, Lux Verbi, Kaapstad.

Daley, B., Schreiner, J. \& Lona, H., 1986, Eschatologie in der Schrift und Patristik, Herder, Freiburg. (Handbuch der Dogmengeschichte, Band IV).

Dawkins, R., 2006, The God Delusion, Bantam Press, London.

Gras, H., [1956] 1961, Ostergeschehen und Osterberichte, 3. Ausgabe, Vandenhoeck \& Ruprecht, Göttingen.

Jackelén, A., 2005, Time and Eternity: The Question of Time in Church, Science and Theology, Templeton Foundation Press, West Conshohocken, PA.

Jüngel, E., [1971], 1973, Tod, 3. Ausgabe, Kreuz-Verlag, Stuttgart.

Moltmann, J., 1966, Theologie der Hoffnung: Untersuchungen zur Begründung und zu den Konsequenzen einer christlichen Eschatologie, Chr. Kaiser Verlag, München.

Nürnberger, K., 2002, Theology of the biblical witness: An evolutionary approach, LIT Verlag, Münster.

Nürnberger, K., 2010, Richard Dawkins' God Delusion: A repentant refutation, Xlibris Books, London.

Nürnberger, K., 2011, Regaining sanity for the earth: Why science needs best faith to be responsible, why faith needs best science to be credible, Xlibris Books, London/ Cluster Publications, Pietermaritzburg.

Pannenberg, W., 1989, 'The doctrine of creation and modern science', in T. Peters (ed.), Cosmos as Creation: Theology and Science in Consonance, pp. 152ff, Abingdon Press, Nashville, TN.

Peacocke, A., 2007, All that is: A naturalistic faith for the twenty-first century, ed. P.Clayton, Fortress Press, Minneapolis, MN.

Peters, T. (ed.) 1989, Cosmos as Creation: Theology and Science in Consonance, Abingdon Press, Nashville, TN.

Peters, T., 1989, 'Cosmos as Creation', in T. Peters (ed.), Cosmos as Creation: Theology and Science in Consonance, pp. 45-114, Abingdon Press, Nashville, TN.

Peters, T., Russell, R.J. \& Welker, M. (eds.), 2002, Resurrection: Theological and Scientific Assessments, Eerdmans Publishing Company, Grand Rapids, MI.

Polkinghorne, J. \& Welker, M. (eds.), 2000, The end of the world and the ends of God: Science and theology on eschatology, Trinity Press International, Harrisburg, PA.

Polkinghorne, J., 2006, 'Christianity and Science', in P. Clayton \& Z. Simpson (eds.), The Oxford Handbook of Religion and Science, pp. 57-70, Oxford University Press, Oxford.

Russell, R.J., 2000, 'Bodily resurrection, Eschatology, and Scientific Cosmology', in J. Polkinghorne \& M. Welker (eds.), The end of the world and the ends of God: science and theology on eschatology, pp. 3-30, Trinity Press International, Science and the
Harrisburg, PA.

Russell, R.J., 2008, Cosmology-From Alpha to Omega: The creative mutual interaction of theology and science, Fortress Press, Minneapolis, MN.

Sauter, G., 1996, Eschatological rationality: Theological issues in focus, Baker Books, Grand Rapids, MI.

Von Rad, G., 1960, Theologie des Alten Testaments: Band II Die Theologie der prophetischen Überlieferungen Israels, Chr. Kaiser Verlag, München.

Wilckens, U., 1970, Auferstehung: Das biblische Auferstehungszeugnis historisch untersucht und erklärt, Kreuz-Verlag, Stuttgart/Berlin.

Wolff, H.W., 1974, Anthropologie des Alten Testaments, Chr. Kaiser Verlag, München. 